\title{
THE SOCIAL RELATIONS OF DISABILITY
}

While disabled people in mining communities worked, sought medical care and received welfare, they also existed in a complex web of social relations. Such social relations were varied and complex, were determined by a broad array of social, cultural and other factors and had profound consequences for experiences and understandings of disability. But just as existing social relations helped influence the experiences of disabled people, so disability brought about new social relations between individuals, groups and agencies. Thus, disability was both reflective and constitutive of social relations, and the question arises whether the varied social relations between different coalfields, themselves the product of a range of disparate factors, led to different social relations of disability in the case-study coalfields.

This chapter considers everyday social relations within coalfield society, and does so from a spatial perspective. ${ }^{1}$ It considers a range of 'public', 'private', interstitial and liminal spaces in which disabled people lived their lives and came into contact with others. The home is, of course, a crucially important location for the production and reproduction of social relations, but disabled people also spent a great deal of their time in the broader community, from public places such as parks, squares and the street to community institutions such as places of worship, sports grounds, cinemas, clubs and pubs, social centres and so on. In adopting this perspective, the chapter draws upon Brendan Gleeson's socio-spatial approach to disability. Railing against the paucity of historical and spatial approaches to disability, Gleeson set out to analyse the 'social space of disability' by exploring the spatial dimensions of everyday life for disabled people in the city. ${ }^{2}$ Convinced of the 'irreducibly spatial character of social relations', he set out to do this through a focus on the home and institutions as significant social spaces for the social construction of disability, in addition to 'interstitial' spaces such as the street or the informal economy. ${ }^{3}$ Through 
consideration of these various spaces, a 'landscape of disability' can be mapped and used to better understand the experiences and understandings of disability in coalfield society.

This attention to spatial perspectives as a means to consider the everyday realities of disabled people's experiences also serves to emphasise the importance of movement - from one place to another, or through spaces - and thereby also gives a better sense of the everyday lives of disabled people in mining communities and the particular circumstances in which social relations were produced. In this sense, space becomes more than mere location or a tangible, physical environment, and more a 'lived space' in which bodily experiences - in addition to cultural norms, political views and other emotions - help to inscribe it with meaning and significance. The spatial approach also serves to prioritise the aspects of life that were important to historical actors themselves, rather than the more intangible, abstract social, cultural and political contexts that are traditionally given greater prominence by academic perspectives. $^{4}$

While the social relations of disability were reflected and constituted in the workplace, as demonstrated in the first chapter, they were also manifest in the two other important spheres of life: home and community. This study has regarded the home as a workplace (mainly of unpaid women servicing industrial workers), while coal historiography since the late 1990s has brought into focus the importance of home and community as spaces in the constitution of social relations in coalfield communities. ${ }^{5}$ The home, in particular, with its gendered divisions of labour and family roles, is a key location in which to address the intersection of male disability and gender. It is also the space most likely to be inhabited - and affected - by disabled women in the coalfields.

Work in disability studies since the 1990s has illustrated how the construction of disability is itself informed by class, gender, race, ethnicity, religion and age, in addition to marital status and family composition. An early feminist disability study, Pride Against Prejudice (1991) by Jenny Morris, was a groundbreaking challenge to the generalisations of social model theory for their failure to adequately include disabled women. She argued that 'a feminist perspective can help to redress [the lack of disabled people's voices], and in doing so give voice to the experience of both disabled men and disabled women. ${ }^{6}$ Other work has seen an intensified effort to address the lack of women's perspectives in disability studies and to integrate feminist theory into an intersectional disability studies. ${ }^{7}$ Likewise, the interplay between disability and masculinity is an important and emerging question. Like Morris, Tom Shakespeare argues that the structural focus of the social model has obscured personal experiences 
of oppression: 'Masculinity and femininity are in a process of transitional change in western societies, which makes it difficult to generalise about the strategies of individual disabled men and women."

\section{Disability and the home}

While the focus in the labour history of mining communities was once on trade unions, strikes and industrial relations, the broadening of the historiography in the 1970s and 1980s led to attention being given to other aspects of the social history of such communities. These included the home, in terms of both the provision and quality of the physical structure and, more importantly, the social institution in which people resided and formed social relations. The best work in this field emphasised the interdependence of the home, the community and the workplace in the production and reproduction of social relations, and the extent to which the home was as crucial a location, in the creation of the mining community, as the colliery. ${ }^{9}$ As a space, the form of miners' housing had consequences for the lives of their disabled inhabitants that helped to condition social relations.

Miners' houses varied in character and quality from one coalfield to the next, but certain common characteristics were evident. They tended to be small, crowded and frequently lacking adequate sanitation, creating multiple health risks in addition to the threat of smoke pollution from both pit and domestic chimneys. ${ }^{10}$ Nevertheless, differences are discernible across different coalfields and would have had a material influence on the experiences of disabled people and their families. In the Scottish coalfields, single-roomed cottages, many dating from earlier in the nineteenth century but others still being built as late as the early twentieth century, constituted almost 20 per cent of the housing stock in some districts by that time. More numerous were the two-roomed houses consisting of a kitchen and a smaller additional room. ${ }^{11}$ In the north-east of England, small, single-storey houses of two rooms - a kitchen and another room - were also common, but both here and in the Scottish coalfields later developments were a little more commodious as houses with two or three bedrooms were built in larger numbers by the end of the nineteenth century. ${ }^{12}$ Houses in mining communities in south Wales, usually built in the late nineteenth and early twentieth centuries, when bye-laws governed the physical character of the buildings, tended to be of this higher quality, with kitchens, bathrooms and two or three bedrooms. ${ }^{13}$ According to the census of 1911, overcrowding (by the census measure) stood at 5.6 per cent of the population in the Rhondda valley and 5.9 per cent in nearby Aberdare, in south Wales, whereas the level was as high as 34.2 per cent in Stanley, 32.2 per cent in Brandon and Byshottles and 41 per cent in Annfield Plain, all in the north-east 
of England. ${ }^{14}$ If levels of overcrowding varied from coalfield to coalfield, the consequences of living with a disability or convalescing in a single room shared with six or seven other people could be severe. ${ }^{15}$ As Carr observes, the houses in the north-east were 'no fit places for the care and rehabilitation of the sick'. The lack of space, the frequent absence of fireplaces or windows that opened, and the poor sanitary state of the housing were inimical to good health, convalescence and everyday life with an impairment. Severely ill or disabled people were required in these conditions to lie on a sofa or bed, or were propped up in an armchair, perhaps in the one living room of the household, where ordinary domestic routines continued. ${ }^{16}$

Homes that were ill-equipped to serve as spaces for disabled people could potentially cause fear and anxiety to families. A Mass Observation report in 1942 aimed to investigate this issue. It recounted the views of a Medical Officer of Health who complained that:

It's all the worse because people here have always taken a great pride in their houses. They are self-respecting people. I had a letter from a woman only the other day. Her son's been invalided out of the Army with tuberculosis. He's got to come back to a house that's running with damp. The letter was most pathetic. But there's nowhere else they can go. ${ }^{17}$

Thus the report revealed the difficulty in reconfiguring houses to accommodate disabled family members in the available domestic space.

The physical form of the miner's house had some influence on social relations, but it was the home, as an idea and as an institution, that was more important in the experience and production of social relations. The relationship between husband and wife in the mining household has long been stereotyped as the breadwinner-worker and the equally hard-working but dependent wife in a clear sexual hierarchy. Gender historians have qualified this generalisation and have challenged one-dimensional or overly broad stereotypes to offer more nuanced portrayals in which love and affection are as evident as any pragmatic utilitarianism and in which wives are not necessarily powerless victims of male authority. $^{18}$

The most obvious way in which disability reflected and was constitutive of social relations was in the context of care giving. In her history of women in pit communities, and also drawing on her family's experiences in a mining village in north-east England in the early twentieth century, Griselda Carr describes women's care for both disabled and temporarily sick husbands: they 'nursed them with tender care, feeding them, helping them to wash and removing the slops. They dosed them with medicines, bandaged and poulticed them, all the while attempting to maintain in a small and often crowded living room as much peace and quiet as they could. ${ }^{19}$ The grandmother of Carr's husband, 
Bill, for example, 'shouldered' the care for two sons, 'one who was born with a short crippled leg and another who was a Down's Syndrome child. ${ }^{20}$

While women's working lives in particular could be transformed by the arrival of a child with a congenital disability, they could also be turned upside down by the sudden permanent disablement of their husbands or sons in industrial accidents. Social relations between previously able-bodied adults in the context of severe head injury, loss of a limb or paralysis could change considerably. Such injuries and conditions were common in mining communities and, given the particular gender relations in these communities, often meant a significant burden of care giving placed on women's shoulders in addition to their usual domestic responsibilities. While such injuries could heal to a greater or lesser extent, even a temporary disablement would have an impact on income and require care giving. The disability of the male worker generated a great deal of additional work for the miner's wife, including taking on domestic tasks usually carried out by the man. One miner from south Wales remembered, for example, how his wife was forced to assume his usual responsibility of carrying in the coal delivered to the front of the house to the coal shelter in the back yard as his strength failed as a result of pneumoconiosis. ${ }^{21}$

Daughters were also required to assume greater responsibilities and assist their mothers in care giving and domestic tasks, even to the extent of giving up their hopes of continuing with their education. ${ }^{22}$ Examples can also be found of parents, sons, daughters, siblings, aunts and other relations who were the sole support of disabled miners, and this serves to remind us of the variation in family and household composition in the past and the complexities of care giving and support for disabled miners. ${ }^{23}$ Slightly differently, it was common for families with sick or disabled members to employ a 'girl' from the neighbourhood to assist with everyday domestic tasks, whether the wife of the miner was present in the household or not. ${ }^{24}$

Interestingly, the miners' union in south Wales used the experiences of miners' wives as care givers in their recruitment campaigns in the interwar period, and in their attempts in the 1930s and 1940s to convince their members of the importance of rehabilitation. This material communicates the considerable physical and emotional labour that faced women when a miner was carried home injured from the pit. ${ }^{25}$ In an article published in the union magazine The Miner in 1946 a miner's wife wrote:

With the means at my disposal, along with the kind assistance of neighbours, I nursed and cared for my husband for eleven months in ... crowded conditions. It was a hard and trying time as I had at this time five young children, the eldest of whom was nine years of age and the amount of compensation I received for this period was $24 /$ - per week. 
She noted how she was forced to do the work required in the garden that year because of her husband's incapacity and was again required to look after him, later on in life, in the eight years before he died, when he was confined to home due to pneumoconiosis. ${ }^{26}$ Given the added demands placed on women by the injuries and illnesses of their male relations within a context of little external support, it is unsurprising that one study from the 1930s found that it was the wives rather than the miners who 'remembered occasions and details of illnesses and death minutely, no doubt on account of their close association with the sickness. ${ }^{27}$

The caring or supporting role expected of men was markedly limited by gender. Men provided or were given money for their families, but were not, on the whole, expected to provide hands-on care. In some instances the lack of practical caring may have been due to competing duties in paid employment. Ramsay Guthrie's historical novel Black Dyke (1904), set in pre-union days, depicts a miner with an invalid wife who has been 'badly', 'On an' off this five yeers, ${ }^{28}$ who cannot 'bide at home' with her, despite his desire to do so: 'His heart was sore in the thought of leaving his wife in her suffering. He was angered at the tyranny which compelled him to do so. A fine of half a crown was the penalty of absence unless a doctor's certificate of personal illness could be produced. ${ }^{29}$ Other examples of men depicted in care-giving roles can be found in literature, even while care continues to be considered 'women's work'. The paralysed miner in the Scottish novel Black Earth is mainly cared for by his wife, but a male collier friend visits to shave him - a specific caring task perhaps considered more suitable for a man because shaving is part of male grooming and associated with barbershop work. ${ }^{30}$ Women are also depicted receiving care from male family members, ${ }^{31}$ such as Ann, a miner's wife in Jack Jones's novel Bidden to the Feast and whose husband becomes one of her main carers after she suffers a paralysing stroke, as his daughter Megan comments: 'Dad'll look to mam. He'd rather, an' she's better with him than with [her daughter] Moriah - or anybody for that matter. ${ }^{32}$

Such emotional engagement with illness and care giving on the part of working-class men was perhaps more easily articulated through imaginative literature than in the macho world of mining communities, but recollections of the time nevertheless suggest that working-class men could transcend their traditional gender roles while away from the judgemental gaze of neighbours and friends, within the privacy of the home. Male care giving is described in Jones's autobiography, Unfinished Journey, when he helps with the care of his collier father, sick with pleurisy. Jones has been working his father's shift in the pit, but realises that, without relief, his mother will also become ill from strain and then 'it would be domino on all of us. ${ }^{33}$ Coalfields literature thus depicts 
a mixed picture of caring relationships between family members. Despite the presumption of female care, and the view that care is 'women's work', male family and friends may also contribute when the primary carer herself is incapacitated or overwhelmed.

Existing gender relations in mining communities clearly influenced this pattern of care giving: apart from the more general, widespread belief in the 'natural' abilities of women as carers, the low levels of economic participation by women in coalmining communities confined them to the home in greater numbers than those women in other urban or industrial contexts. But it is also clear that such care giving brought about new gender relations as the usual roles of men and women, particularly the former, changed. Disability within mining culture, with clearly prescribed gender roles, had profound consequences for men and their sense of themselves.

It is extremely difficult to get a clear sense of the psychological impact of disabling injury and impairment on men and their sense of masculinity in this particular context. Documentary evidence, is scarce since social relations in this context were unremarkable, everyday aspects of home life and did not, therefore, give much cause for comment or discussion, especially where they might have involved feelings of shame and inadequacy. In addition, large numbers of disabled workers, particularly those who suffered paralysis, would have suffered social isolation in the home as a result of their inability to join in the usual social activities of mining communities and the absence of any contact with other people. Nevertheless, careful scrutiny of a range of historical, autobiographical and literary sources can help to sketch some of the main aspects of the impact on masculinity and some sense of the social isolation experienced by many disabled people.

What we can infer from the historical sources and literary depictions is that the strength of the breadwinner model and ideals of masculinity in mining communities meant that physical impairment that prevented work and social interaction was disabling in social terms. Miners prided themselves on their physical strength, skill and capacity for hard work and these conferred status and prestige within the occupational and broader community. The loss of income and status contingent on disabling injury, on top of the impact on a man's ability to perform his role as head of the household and an active member of the community, would have had a considerable impact. In addition, impairment and a period of convalescence at home removed the man from his 'masculine' public sphere of work and, possibly, from community social life and confined him to the 'feminine' private sphere of home, though, as we shall see the separation between these spheres was not as binary as the division suggests. Nevertheless, a disabled worker's usual means of performing his masculinity were removed 
from him and he was he was left without the main aspects of his life by which he defined himself.

Durham miner-writer Harold Heslop's The Earth Beneath (1946) portrays the impact of permanent disability following a mining accident in the character of Butch, a typical 'big hewer' figure whose 'biceps almost burst his shirt sleeves at times. ${ }^{34}$ Butch is injured in a roof fall, fracturing both legs and his back; his left leg is permanently shortened and even with the aid of two sticks ' $[\mathrm{h}] \mathrm{e}$ hobbled painfully ... [w] henever he jarred his back the pain almost made him faint. ${ }^{35}$ Butch remarks to a fellow miner: 'It's rotten lying waiting for the bones to knit, George. And it's very painful, hinny. Ye're so helpless, if ye ken my meaning. ... I'm done, laddie ... A man knows when he's done, George. ${ }^{36}$ It is both the physical pain and his changed role in the family that causes him distress; he is 'done' and 'helpless' because he 'had been forced to lay aside the task of bread-winner. ${ }^{37}$ Heslop portrays Butch's response as typical for a miner:

To the miners it was a tragedy that the power within the muscles of a comrade should be sapped and wasted before its time. A man never retired from labour in their sphere. He stepped from the mine into the grave, his work done. And the sexton covered up his shame. To be cut off as Butch Rowlands had been cut off was a gaping tragedy. ${ }^{38}$

In spite of the severity of this statement, Heslop describes how Butch and his wife get by, in part through the support of the community. They have a collection of money from the colliers to start with, occasional donations of a shilling, tobacco or a fish from their friend George, and Butch's wife also works harvesting fields, making mats and selling nettle beer. Butch is still active in the community through participation in chapel life. ${ }^{39} \mathrm{He}$ was a lay preacher before his injury; now, with physical support from George, he attends chapel weekly, passing comment on visiting preachers: 'for Butch, if he could not preach, could mount guard on God's word. ${ }^{40}$ So, although Butch is 'cut off' from performing the masculine role of 'bread-winner', though he cannot walk unaided and is prone to fainting (a condition gendered as feminine), Heslop's novel ensures that this 'gaping tragedy' is mitigated by the support of comrades such as George and a network of community support, particularly the chapel in this case.

In addition to the individual strains faced by miner and wife under the changed circumstances of a serious injury or impairment, the relationship between husband and wife inevitably evolved. Few historical sources address this emotional cost on miners' wives, but writers took up the issue in their work. In Joe Corrie's Black Earth, Jack's paralysing injury from a roof fall portrays the emotional strains of his disablement and its toll on his wife, Maggie: 
It seemed that he was terrified she should go out of his sight lest something should happen to him. He couldn't bear to have her out of his sight. ... Maggie had to do everything. Twice a week Tom Marshall came in to shave him. Even that obligement wasn't appreciated, for he hated the process. But Tom persisted. ... Jack was either silent or abusive. Tom knew only too well that Jack couldn't help it and would curse himself at times for thinking that he might show more patience and reasonableness lying there. But he saw how Maggie was breaking down under the strain. Day after day the same, never sitting down for a minute but he wanted something. It was more than any woman could stand. A pity that he hadn't been killed that day. ${ }^{41}$

This passage, including its shocking final thought, utilises many of the 'burden' and dependency tropes of disability in literature and culture. Yet its portrayal of frustration and anxiety from both the injured miner, family and friends in the weeks and months after a life-changing injury was, for many mining families, very real.

Disablement of the main breadwinner, whether temporary or permanent, also brought about a reconfiguration of social relations between fathers and their children. The contemporary definition of masculinity cast the man as a father with responsibilities to his children as much as a husband to his wife, and disability had consequences for this part of the man's identity and social relations also. In the first instance, disability, and particularly the reduced income brought about by its effects on earning capacity, led some families to limit family size and have fewer children, and this was especially the case during the interwar economic depression. More to the point here, existing children were often forced to start work earlier than they might have done otherwise, rather than continue in education, or else assist with the domestic tasks in the home. ${ }^{42}$ Sons, especially, were expected to take on the responsibility as primary earner. In a 1973 interview the Welsh miner Dai Daniel Rees discussed the need to step up when his father 'failed' from pneumoconiosis: 'I was the eldest and I had to keep working. That is how I started a bit sooner like see. ${ }^{43}$ Similarly, John Paterson remembered having to leave school and start work at fourteen as his father's health failed as a result of pneumoconiosis in the Lanarkshire community of Benhar. ${ }^{44}$ This entailed an immediate change in the financial responsibilities within the family and, depending on the particular personal relations, possibly the status and authority of the different individuals within the family.

The sense of duty and responsibility on the part of sons for their old, infirm or impaired parents was given official force by practices within state welfare policies, especially the Poor Law. ${ }^{45}$ For example, the Aberdare Times reported in October 1894 on two brothers summoned to court 'to show cause why they should not maintain their father', who was described as ' 75 years of age and a 
cripple.' The brothers' own family situations were examined: one was a 50-year-old widower, the other had a more complicated scenario - 'when his wife was ill he wanted him [the father] to try and get a place with his sister Mary. John said he was willing to pay ... and wanted the old man to be kept in the Union.' The ruling found that both brothers should continue to pay for 'the old man." Poor Law officials in Scotland in the late nineteenth century bemoaned the lack of commitment to the welfare of parents on the part of some children and were keen to compel sons and daughters to acknowledge their responsibilities and contribute to the upkeep of their parents. ${ }^{47}$

In other instances, the disability of the male breadwinner meant that his children were not able to enter the world of employment and were required to assist in the home, and this was especially the case for daughters. A Poor Law Relieving Officer noted the case of a miner in Blaina, south Wales in 1926 who had been out of work since 1921 as a result of a fractured spine. He had a wife and three dependent children, and his sixteen-year-old daughter was 'unable to take up domestic service. Needed at home to assist to nurse her father. ${ }^{48}$ It seems unlikely that such a change in the relations between this man and his daughter transformed the authority that he held over her as her father, but subtle changes in their relationship, on an emotional as well as a practical level, would seem to be entirely likely. It was a common practice for daughters to leave school at age fourteen to help mothers with domestic tasks, and this would seem even more likely in the event of the impairment of the father in the family. ${ }^{49}$ David Meek, a collier from Bothwellhaugh, Lanarkshire remembered how, when his mother developed multiple sclerosis, his fifteen-year-old sister would rise at five o'clock in the morning to prepare breakfast for his brothers and their father; the work became too much for her, since she was also responsible for looking after the younger children in the home, and he, his brothers and his father simply made their own breakfasts from that point onwards. ${ }^{50}$ Significantly, though, the added burdens assumed by girls in these situations not only affected their position in the family but also had consequences for their own well-being and future pospects.

While some historians quite correctly emphasise the extent to which state welfare policies classified men as providers and women as dependents, and ensured that the traditional gender relations were upheld, it is nevertheless possible to discern some cases in mining communities where daughters became the primary supporters of their impaired parents. For instance, the records of the Bedwellty Poor Law Union during the 1926 miners' lockout frequently demonstrate the extent to which daughters were made financially responsible to make up for the loss of income brought about by the illnesses and impairments of their fathers. One head of a mining household in Abertillery, for example, 
was listed as having gastroptisis with an income of 'self', National Health Insurance, and ' 4 daughters working at the laundry earning 19/-. Two sons were listed as unemployed. ${ }^{51}$ This was an extreme case, in the particular circumstances of 1926 when any adult sons would have been out of work, but it reflects the necessity of children in mining families, including daughters, contributing to the household income in the event of impairment, or even being the main support for their fathers.

At the same time, it would be simplistic to argue that disability led to emasculation and the complete reordering of gender relations in the home. The period of convalescence did not constitute merely the absence of work and its replacement with the 'female' aspects of the domestic environment. Various adjustments were necessary that marked this out as an unusual period in the life of the family in which the usual gender norms did not, perhaps, operate. For example, working-class families adjusted their living arrangements to meet the impaired mobility of the injured miner, often through setting up a convalescent bed in the front parlour or 'living room' on the ground floor. ${ }^{52}$ This reorganisation of the normal domestic arrangements marked this out as a period in which the usual norms did not apply, and so might have mitigated any emasculation to some degree.

Other aspects of the experiences of disabled and convalescent miners undermine any tendency to offer easy generalisations of emasculation. Some miners took up hobbies or interests that, on first sight, had traditionally feminine connotations, but adopted them on their own terms and according to a more complex sense of masculinity. Janet Chapman remembered that her father, who worked at the Kinneil Colliery in the Midlothian coalfield, took up baking 'and he wis a lovely baker, he wis. And he wis great. He wis gettin' on great tae he took ill and he wis moved tae the Deaconess. ${ }^{53}$ This is of course, only one example but it hints at a home life and identity beyond that of 'injured miner', via activities that traditionally did not fit stereotypes of masculinity. ${ }^{54}$ Perhaps the best illustrative example of the complexity of experiences from the effects of disability on masculinity can be seen in the case of George Preece (Figure 4). He lost both his legs following an accident undergound at Abercynon in 1909 and went to live with his niece and her children, where he developed an interest in crocheting. One piece of Preece's crocheting work that has survived consists of an image of a battleship (Figure 5). ${ }^{55}$

Even in the absence of waged work or any interest in masculine hobbies and activities, it was still possible for wholly isolated disabled ex-miners to maintain some semblance of their masculine identity and their position as the source of the family's well-being. The continued performance of traditionally masculine duties by disabled miners, and its role in the avoidance of complete emasculation, 


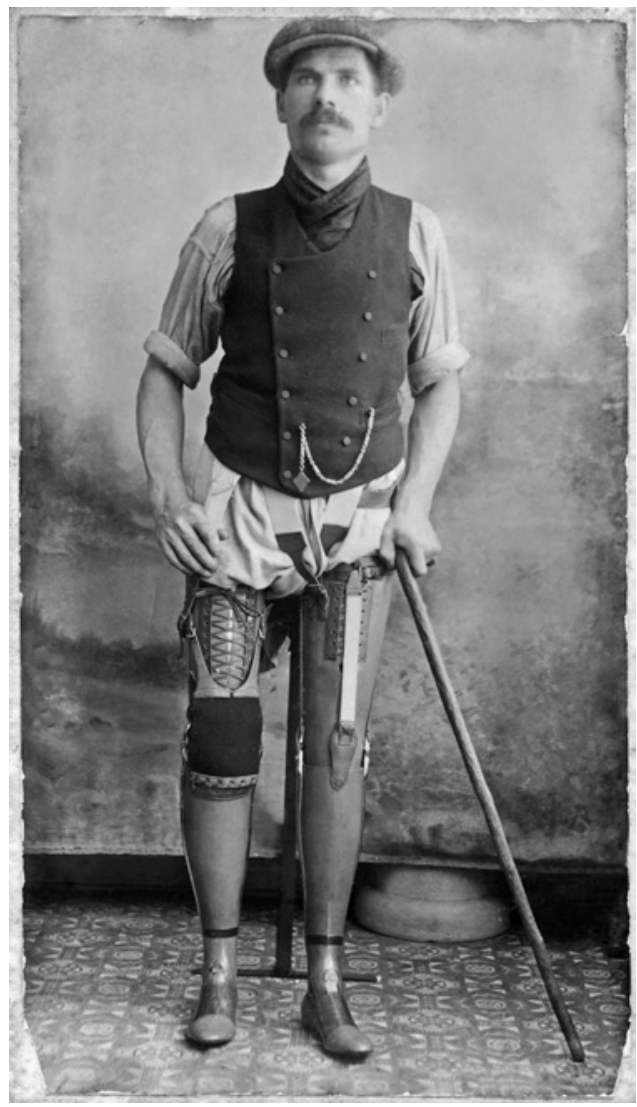

4 Disabled miner George Preece, c.1909

was made possible as a result of the welfare provision that a worker made before becoming impaired. Trade unions, friendly societies, medical schemes, commercial insurance companies and other self-help and mutualist agencies appealed to the masculine identities of workers and their responsibilities to their dependent wives and children. In a leaflet published in 1936, for example, the South Wales Miners' Federation listed some compensation cases that it had won on behalf of local miners and urged miners at Bedwas to support the union. It told them 'Let your Wife and other Dependents see how you are stripped of all protection by being outside the Federation. Let them see how you are cruelly risking all their interests, and robbing them of all help and guidance should anything happen to you. Their protection and yours is the Miners' Federation. ${ }^{56}$ In return 


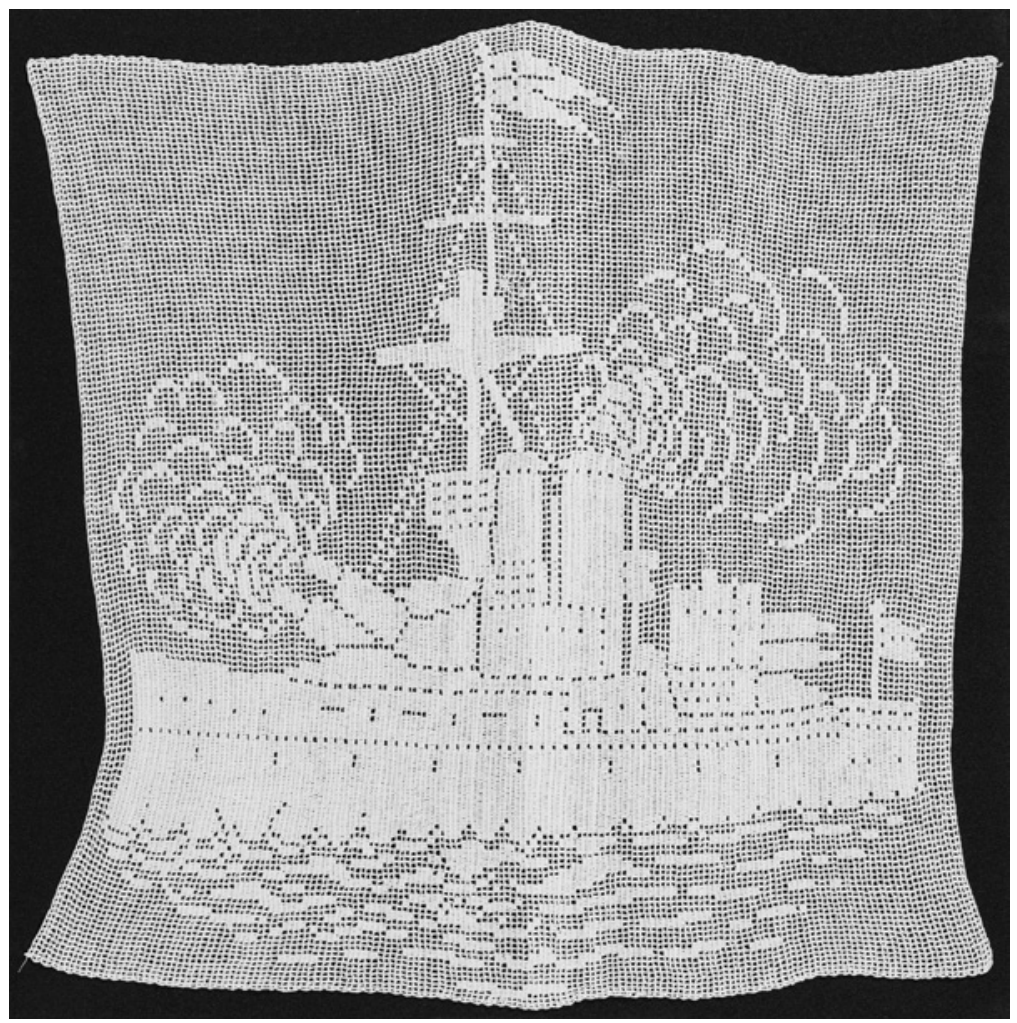

5 Crochet panel depicting a naval gunship made by George Preece during his re-habilitation after a mining accident at Abercynon Colliery in 1909

for membership of the union the miner would gain eligibility for union assistance to pursue compensation claims and for the support of his dependent family members; the friendly societies offered sickness benefits to assist the family during times of illness and incapacity. In these ways, through the payment of compensation or sickness benefits, an injured miner could feel that he was continuing to play the breadwinner's role even in the absence of waged work and was encouraged to think that he was doing his duty as a man.

This insistence on the male breadwinner model as the basis for gender relations, and its encouragement whatever the circumstances, was further strengthened in the cases of disabled miners who were still cast as providers with responsibilities for 'dependents', despite a reduced income as a result of their impairments. An 1887 court case in south Wales reported by The Cambrian newspaper demonstrates what happened when this contract was broken, when 
a disabled miner, 'a lame man', appeared in court 'for not complying with an order of $4 \mathrm{~s}$. per week made upon him towards the support of his wife'. The miner was ordered to pay $£ 1$ of the money owed to his wife within a fortnight or spend a month in prison. ${ }^{57}$ Thus, just as the welfare and legal systems compelled children to take responsibility for their impaired fathers, they also ensured in other cases that disabled miners, where possible, continued to play their role as 'independent' men with responsibilities to dependents.

More than any other factor, however, it was perhaps the sheer power and customary character of male dominance that reduced the possibility of complete emasculation and ensured that the man's position as head of the household endured. Jim Bullock, a miner and later mine manager in west Yorkshire, remembered that his father finished work in 1903 at the age of fifty-three as a result of rheumatism, and that, while he now became dependent on adult sons who earned enough underground to support him and the rest of the family, he remained the 'king in his own home. ${ }^{58}$ This was surely replicated in a great many other cases: members of a miner's family were long accustomed to his authority and status as the head of the household, and neither impairment nor disability, whether temporary or permanent, was likely to erode these things completely.

Not all miners who became disabled were married, and not all disability in coalfields communities was the result of industrial accident. The consequences of disability on marriage prospects, particularly where young disabled people were not economically active, are not well documented, but it is likely that they faced difficulty in forming relationships. Few sources exist which address this directly, but the 1997 testimony of Janet Chapman offers some insight. Chapman was a 'pithead lassie' who lived with her father (born in 1893 and died in 1947), a despatch clerk described as 'hunchback' who worked at Kinneil Colliery in Scotland. An interview with Janet hints at the emotional bonds created by the family structures, and also the prejudice and hostility faced by disabled members of the community when they intended to marry:

Mother wis Bo'ness wumin. Ma father wis in a wheelchair when ma mother met him. She married him when he wis in the wheelchair. That she did. Ah know that.

[Interviewer: That took courage, that took courage, aye?]

It did. It did, aye. That's why the folk used tae say tae her that she wis bein' stupid, you know ... And bein' honest, ma gran, Rintoul, ma father's mother, didnae want ma father tae get married tae ma mother. She didnae want him to get married at all because he wis ... wi' him bein' in the wheelchair and that, she jist did not want it to happen. But ma father wanted tae marry ma mother, and that wis it. ${ }^{59}$

Chapman's testimony hints at a desexualisation of miners and prejudicial barriers to their relationship and marital possibilities, but it is also evidence of at least some people being able to see beyond disability as 'disqualification.' 
Sexual and marital relations are explored in coalfields literature, most notably in depictions of miners who become paralysed as a result of a mining injury. ${ }^{61}$ The changed relationship between husband and wife, Jack and Maggie, is a central focus of crisis in Scottish miner Joe Corrie's Black Earth. Jack worries that, without his ability to provide for Maggie, either as 'breadwinner' or as a marital partner, she will want to seek out a new sexual partner: 'she had no more use for him. Standing there, the healthy animal that she was, thinking, no doubt, that she should have another man. Ay, that's what was wrong with her, the greedy vixen. ${ }^{62}$ Jack's changed personality, being cold and angry towards his wife, is related to his feelings of fear and powerlessness: 'It wasn't people he hated so much as life, ay, that's what it was, and life to him meant the long days in that bed, and Maggie, full-breasted, in perfect health, for ever in his sight. And yet when he thought of death he would tear at the bedclothes in fear. He was a coward, yes, he was a coward. ${ }^{\prime 63}$ Jack feels taunted by the sight of his wife, particularly because he cannot be a sexual partner in the traditional phallocentric sense. A medicalised focus on male sexual function is highlighted by Tom Shakespeare as 'particularly oppressive and undermining of disabled men. ${ }^{64} \mathrm{Jack}$ here focuses on the physical aspect of his marriage; as for Maggie, she is particularly hurt by losing his emotional support: 'never once had he asked how she was managing to carry on ... it was indifference to them all that hurt her. ${ }^{65}$ The qualities she misses are related as much to his personality as to his physical ability; she prays for him to return to 'the man who had no selfishness in him, the man who could laugh, the lover of the early days and the father of the latter days, the man who could take a drink, who could sing a song, who could look forward and see peace and happiness at the end of things. ${ }^{66}$ Disability has disrupted the marital relationship in both physical sexual and emotional terms; it is a crisis which has been gendered by the husband focusing more on their sexual relationship and the wife focusing more on their emotional relationship. Jack is not despicted as asexual; rather, his crisis stems from frustration that he cannot act on his continued feelings of sexual desire, and he feels that this brings his masculinity into question.

Thus disability had various, complex and conflicting consequences for a man's masculinity and his affective, sexual and social relations with members of his family (and his ability to form a new family), but it also altered the position of women and their relations in the home. Unsurprisingly, the assumption of care and emotional work by miners' wives had the potential to render women's own disabilities invisible. As Carr states, 'Although they were the linchpins of their families' survival, most of the women almost totally neglected their own health. ${ }^{67} \mathrm{~A}$ sense of sacrifice for the sake of the rest of the household was 
assumed here, with less rest, poor diets and rare doctor appointments creating ill health and disability. Thus, the physical and emotional labour involved in mining women's care for disabled family members exacerbated the strains that their bodies experienced and made their own chances of debilitating conditions or permanent disability that much more likely. ${ }^{68}$ At times the strain was too much, and instances can be found of miners' wives petitioning the Poor Law authorities to admit their disabled husbands into the workhouse; one miner's wife at Easington, County Durham nursed her husband for two years after he fractured his spine but felt compelled to have him admitted to the workhouse after she was diagnosed with stomach cancer. ${ }^{69}$

The home was clearly a significant space for the production and reproduction of the social relations of disability - or, in Gleeson's terms, an important 'social space of disability' - but it also acted as an important liminal space. Providing as it did the space in which injured, impaired or sick miners convalesced, the home can be considered as a transitional space between impairment and ablebodiedness (or, at least, a space in which a worker transitioned to a state of reduced impairment) in addition to a threshold between the private world of family and the public world of neighbourhood. Indeed, such a conceptualisation of the home collapses the public-private binary and emphasises the interpenetration of these two spheres of everyday life.

\section{The home as a liminal space: neighbours and community}

As we have seen, mining communities' systems of welfare and support were not limited to the formal, organised societies, unions and clubs. Women provided a massive amount of unpaid care-giving and emotional labour in the home, but they did not do so alone or in isolation. Many historians of working-class life have emphasised the close relationships between neighbours within a locality and the interdependence that facilitated survival in the face of poverty and hardship. ${ }^{70}$ Oral history accounts place emphasis on the everyday interactions with neighbours as a crucial form of support and care for disabled members of the community. This is seen in Bruley's oral history of women in the south Wales coalfield:

If a misfortune occured, neighbours would close in, usually bringing cawl (broth) or Welsh cakes. They would take home washing, look after children and take turns to nurse the sick or injured. Oral history respondents were keen to tell me how strong the bonds of community were. ${ }^{71}$

Disability, then, is included as part of 'misfortune', with an unspoken but assumed bond between neighbours and friends to help when it occurred. The automatic 
division of nursing and care labour seen here shows how common it was, and how communities helped each other.

This was not specific to south Wales. Carr, in a discussion of neighbours in the north-east of England coalfield, noted the many different people involved in care for men's long-term sickness: along with 'panel' National Health Insurance doctors and district nurses, miners got 'support from relatives and neighbours as well as from the older women "healers" of the village'. Carr's concession, though, that 'mostly they [i.e. miners' wives] shouldered their responsibilities with a sturdy independence', hints at the limitations of neighbourly care. ${ }^{72}$

Even in the absence of active involvement of friends and neighbours in care giving, the social isolation of disabled workers in the home was broken down in other ways, and these again stress the interpenetration of home and neighbourhood, marking the house as a liminal social space of disability. The experiences of the Welsh writer Edward Young offer an instructive example of the interconnectedness of the 'private' sphere of the convalescent's sick-room, on the one hand, and the 'public' sphere of work, politics and community matters on the other, and the falsity of any hard and fast divide between the two. Young worked in the local tinplate industry in Pontardawe in the Swansea valley, south Wales before becoming a collier and, under his bardic name Eos Wyn, achieved some local fame as a poet from the 1860s onwards. Following a bout of smallpox in his early twenties, however, Eos Wyn gave up work in the colliery and was confined to his bed by complications that left him in considerable pain and dependent on laudanum for the rest of his life. Nevertheless, he continued to compete in eisteddfodau (cultural festivals) and to publish poems in local newspapers. More importantly, he started to author a regular column entitled 'Ystafell y Cystuddiedig' ('The Convalescent's Room') in a local newspaper until his death in $1892 .{ }^{73}$ The authorship of this column, which focused on a range of issues including the state of local trade and industries, the struggles between Anglicanism and nonconformity, local and national politics, and other social and cultural issues, was itself an involvement in, and contribution to, the public sphere of ideas, discourse and discussion.

Not every convalescent miner could enter the public world through journalism or publication, of course, but Eos Wyn's column suggests another way in which the boundary between public and private worlds, male and female spheres, could be traversed or even made insignificant. Some of the earliest editions of his column were written in the form of a conversation between a convalescent patient and a group of acquaintances and former work colleagues upon their visit to see him in his sick-room. The conversations included discussion of his condition and his attitude towards his impairment, but also ranged widely over such topics as the international situation, school boards, chapel and church 
rivalries, political reform, the local fair and a range of other issues. ${ }^{74}$ Eos Wyn would often comment in his column on the visits he received from well-wishers; in this way, through such visits to a convalescent acquaintance, the outside world of work, politics and other masculine issues was brought directly into the private sphere of the sick-room, which itself came to form a liminal space between the home and the broader, public community.

In addition, this intersection of public and private spheres was also achieved through more formal and communal visits to Eos Wyn's home. Local columnists, writing a form of local travel writing in which the literary personalities of any locality warranted a visit as much as any waterfall or mountain vista, urged other poets and litterateurs to call by Eos Wyn's home if they happened to be travelling through the area. ${ }^{75}$ Similarly, his columns often noted the passers-by he encountered while sitting at his front door during spells of good weather. ${ }^{76}$ More interestingly, a Sunday school treat at which 600 children and old people were provided a banquet of food in May 1872 ended with a procession that called at Eos Wyn's house and performed one of his compositions 'Y Gwanwyn' ('The Spring') outside his home and within his hearing. ${ }^{77}$ A little later, in 1874, a procession of two local lodges of the Oddfellows stopped at his house and the accompanying brass band played a tune while he listened from his chair at the front door. ${ }^{78}$ His brothers in the Oddfellows also bought him a carriage that could be pulled by a donkey, enabling him to leave his home and gain some mobility in the community. In these ways a prominent member of the community, best known for his literary and other cultural activities, was not isolated in his home by his disability and continued to be considered a valuable member of his community.

Such activities were not replicated in the cases of most disabled miners, but visiting sick or impaired friends and work colleagues must have been common in these close-knit communities. Indeed, the practice of moving a convalescent worker, and even sick parents, wives and children, downstairs helped to facilitate such interactions and counter some of the negative, isolating effects of impairment, and this comes through strongly in coalfields literature. ${ }^{79}$ A young new pastor in a 1934 novel notices the difference between visiting 'the loving ones in the kitchen' (loving because they are welcoming to him as a guest) who are 'the sick and very aged, some seated or lying on the couch in the kitchen', and the experience of visiting those with 'senile decay, consumption, cancer, spinal trouble, all sorts of diseases, "upstairs out of the way". 80 To be 'upstairs out of the way' is isolating and implies that illness and disability is being hidden from the more public, downstairs areas of the home, where family (and often visitors or neighbours) come and go freely. In this way, to be downstairs was practical, but was also shown to serve an important secondary function in keeping the 
family member involved in day-to-day family life and facilitating visits from other individuals.

Furthermore, any injured or sick miner in receipt of sick pay from a friendly society was visited by one or more of his brothers in the society, partly as a means to guard against malingering but also as a practical manifestation of the fraternity that stood at the heart of these mutual organisations. Thus, impaired miners, whether temporarily or permanently confined to a sick-bed, were not necessarily isolated completely from their communities and continued to remain part of the social relations that characterised their occupational and community groups.

Nevertheless, care needs to be taken not to overstate this form of interaction or to under-estimate the considerable social isolation faced by many impaired miners. James Hanley noted the case of a miner paralysed in his work who had lain in his bed for eleven years, 'a permanent cripple, without any hope', 'shut off from all activities, intercourse and seeing the life about him', but he used this case as an explicit analogy of the south Wales economy in the interwar depression, and so the accurate portrayal of lived experience seems less of a priority here. ${ }^{81}$ Willie McGill, a miner who worked at Sanquhar, Dumfriesshire, remembered that the pit was a dusty one and that a great many of the workers contracted pneumoconiosis. He noticed that as old men they were soon confined to the home after they finished work in the industry: 'See, whenever they retired, whenever they retired, ee maybe seen them for six month, and ee never seen them again, ken. ${ }^{82}$ Such perspectives would seem to coincide with Gleeson's characterisation of the home as a space that isolated disabled people, but other evidence presented here suggests that in working-class, mining communities the home could function as a liminal space in which friends, neighbours and members of the extended family visited, socialised and assisted impaired individuals.

\section{The street: disability in interstitial spaces}

Following a period of convalescence in the liminal space of the home, most impaired individuals, excluding paraplegics perhaps, were able to enter other spaces and come into contact with other individuals with whom they entered into social relations. In the first place, such impaired people entered what Brendan Gleeson has described as 'interstitial' spaces, such as the street, the informal economy and other places in the public sphere. ${ }^{83}$ Indeed, for Gleeson, the street, at least in terms of industrial communities, is the space in which disabled people were most visible, in contrast to the home and institutions that isolated them from the community at large and confined them out of sight. ${ }^{84}$ 
The ubiquity and visibility of impairment in coalmining communities, of streets 'thronged with the maimed and the mutilated', is a striking feature of the writings of a number of observers, especially of those writers from outside these mining communities who observed the extent of impairment for the first time. ${ }^{85}$ Touring south Wales in 1887 , for example, two socialist missionaries noted the 'plentiful crop of cripples' whom they observed in Dowlais. ${ }^{86}$ In a later period the Polish sociologist Ferdynand Zweig interviewed a miner for his 1948 study Men in the Pits, who told him: 'Can't you see for yourself the number of disabled men with amputated legs or arms or fingers, or even blind, or with twisted spines or necks, or otherwise laid on their backs?' For his part, Zweig agreed with this impression: 'Nowhere else can you see the same relative numbers of disabled men as in a colliery village. ${ }^{, 87}$

Such comments clearly testify to the visbility of impairment in mining communities, but they also pose intriguing questions. Did such visibility and ubiquity lead to greater acceptance of disabled people in mining communities? Did their presence in such large numbers on the streets make impairment an unremarkable and everyday reality of life? Or did their impairment mark them as different in an ableist society and lead to isolation? One clue, perhaps, is offered by Ernst Dückershoff, a German miner who worked in a Northumbrian pit at the turn of the century. In his study of How the English Workman Lives, Dückershoff noted the presence of 'cripples' begging in the street because 'they [had] long since spent the money they received as compensation and can make no further claim, ${ }^{88}$ Dückershoff, writing with the more comprehensive social insurance system in Germany in mind, saw such begging as a failure of welfare provision in British mining communties, and it is possible, given the importance of respectability in working-class communities and the strength of the breadwinner model, that begging in this manner involved a significant degree of social marginalisation for disabled miners.

The 'cripples' whom Dückershoff witnessed begging in the street were not only located in an interstitial space, between the home and the institutions of the public sphere, but were also located in the interstices of the economy, forced to resort to begging to obtain some sort of income. Another example of such a combination are the disabled ballad singers who performed in the street to earn an income, many of them in coalfield districts and some of them former miners. ${ }^{89}$ Ballad culture was strongest in pre-literate communities, before the advent of mass education and mass communications, but could still be observed in late nineteenth- and early twentieth-century Britain. Ballad singers would sing their songs or sell their ballad sheets on the street corner, in the market or at local fairs in order to raise money, often for themselves but also for other causes in the community such as other disabled individuals, the widows and 
'orphans' of colliery disasters, or striking miners. Some of the most famous ballad singers in nineteenth-century Wales used bardic names that testified to their impairments (Richard Williams was Dic Dywyll (Blind Dick), Levi Gibbon was Y Dryw Dall (The Blind Wren) and Lewys y Goes Bren (Lewis with the Wooden Leg)), which were a major factor in their entry into ballad singing. Similarly, in the north-east of England, Tommy Armstrong, the 'Pitman's Poet', gained fame and a modest income from his songs after giving up work in the pit as a result of the impairments caused by childhood rickets and a serious accident underground. ${ }^{90}$

More intriguingly, some ballads gave first-hand accounts of the experiences of these disabled singers and might be considered the type of 'vernacular' and 'experiential' - as opposed to 'institutional' - sources that Elizabeth Bredburg praised as essential to disability history. ${ }^{91}$ Not only do they testify to the precarious financial position of disabled people in the period, but they also comment to some degree on the social relations that existed between impaired ballad singers and others in the community. In 'Mwnwr Tlawd' ('Poor Miner') for example, the singer recounts his experience underground when a fall damaged his spine, while in 'Cwyn y Cloff' ('The Lame Man's Lament') the balladeer explains how he migrated from rural west Wales to work in the mines of Glamorgan but lost his leg to an accident. ${ }^{92}$ The financial imperatives that drove these 'singers of the penny songs' onto the roads were highlighted in the ballads. ${ }^{93}$ William Bowen, a ballad-singer who lost his sight after an accident in Penycae, Ebbw Vale, sang:

Gwraig a phlant a ymddibyna Am eu bara yn ddiball,

Ac edrychant am gynhaliaeth Trwy ymdrechion cantwr dall; Myned i bob ffair a marchnad, Teithio'r hollwlad raid yn siwr, Dyma dynged William Bowen, $\mathrm{O}$ ! tosturiwch wrth y gwr.
A wife and children depend on me For their bread without fail, And look for sustenance Through the efforts of a blind singer; Going to every fair and market, Travelling the whole country surely, This is the fate of William Bowen O! Pity the man. ${ }^{94}$

Thus the ballad singer occupied an interstitial space - the street - in an interstitial part of the economy (i.e. informal, insecure, low paid), and it might also be argued, following Rosemary Garland Thomson, that ballads were perhaps more than a mere niche in the economy and means of subsistence, and can be conceived as a means to handle disability and negotiate interactions and social relations with non-disabled people. She argues that in their encounters with non-disabled people individuals with impairments must learn to manage relationships from the beginning and 'use charm, intimidation, ardour, deference, 
humour, or entertainment to relieve nondisabled people of their discomfort'. 'Those of us with disabilities are supplicants and minstrels,' she argues, 'striving to create valued representations of ourselves in our relations with the nondisabled majority. ${ }^{95}$ If successful, these strategies neutralise the stigma of disability and create the context in which more meaningful relationships can be formed between disabled and non-disabled people, and the personhood of disabled individuals is allowed to develop more fully. ${ }^{96}$

While impaired miners were visible on the streets of mining communities, they could also be seen in other interstitial spaces. Many writers on working-class life in the late nineteenth and early twentieth centuries have commented on the close proximity of housing in working-class districts and the resultant lack of privacy. Campbell, for example, notes how the 'physical constraints of household space ... fostered a communal street culture in the areas immediately surrounding houses. ${ }^{, 97}$ This is most evident in mining communities, and especially in the case of terraced housing with little available space around the house, in the practice of inhabitants of the houses sitting out on the front door-step or the pavement on a stool when the weather allowed. And this was exactly the practice of injured and sick miners during the late nineteenth and early twentieth centuries, where they were able to greet passing neighbours and friends, engage in conversations and renew their relations with members of the community. In the novel The Back-to-Backs, the author describes a sunny day in the community of Haggar, where elderly people and men impaired by their work in the colliery are brought out of their homes to enjoy the good weather. 'Every form of mutilation was exhibited on the pavement,' Grant wrote. 'Every cottage seemed to have at least one hopelessly mutilated inhabitant. ${ }^{98}$ In a not dissimilar situation, the social function of this practice in the creation of affective ties in the community was emphasised in Bert Coombes' account of a Whit Sunday procession of the chapels in his community in the Neath valley in south Wales. Coombes wrote that it was not so much a procession as a 'saunter', since older and infirm members of the community took their place in the ranks of the marchers. More than that:

the many cripples, or the helplessly old who manage in some way to get to the front doors, must have their greetings, too. No old friend must be passed, and by the time an old man has forsaken the lead to totter across and shake hands with some old crippled friend, and returned to his place for the walk to be resumed, quite a time has passed. ${ }^{99}$

Some such men, including Gwilym, a pneumoconiotic miner, Coombes noted, were not able to get to leave their beds and watch the passing procession. Nevertheless, the front door-step, and the pavement immediately beyond it, 
was an interstitial space occasionally inhabited by impaired miners, and one in which social relations could be made and renewed.

Other spaces in the community became important locations for disabled miners to congregate and, interestingly perhaps, form some sort of community among themselves. The pneumoconiosis catastrophe of the 1930s and 1940s in south Wales focused attention on the sufferers of this particular occupational disease and their everyday lives and social position in mining communities. In her study of pneumoconiotic miners in south Wales in the early 1930s, Enid Williams commented on the old and infirm miners who gathered in Aberdare public park each day: 'Anyone would notice that the majority of these men had aged before their time and that they were very short of breath and frequently coughed.' ${ }^{100}$ Similarly, the miner-writer Bert Coombes wrote that 'Practically every fine day I see a group of about a dozen men around the war memorial in the village near here. To use a local phrase which applies to them "their chests have gone." ${ }^{101}$ At Ammanford, another community in the anthracite district, 'silicosis' was said to be claiming 'victim after victim'; 'frequently sufferers are to be seen in the streets of the town gasping for breath', it was reported. $^{102}$

Such instances confirm Gleeson's observation of physically impaired individuals in the industrial city that 'their frequently-restricted ambulance conditioned a different type of participation in streetlife, usually the fixed occuaption of a key node, such as a street corner'. Gleeson was referring to physically disabled people with limb, spine or nervous system impairments, but the point is also true of these pneumoconiotic miners whose impaired lung capacity made walking through these spaces difficult. ${ }^{103}$ The observations by Williams and Coombes perhaps also suggest some sort of comradeship of disability among impaired former miners, an identity of interest perhaps and co-dependency, but they also emphasise the altered reality for these men who found themselves denied their former roles as workers and were now required to exist in an interstitial limbo between the spheres of work and home. However much sympathy and practical support their former work colleagues offered to disabled miners no longer able to work, their apartness was emphasised on a daily basis and it is no surpise that one of these victims of pneumoconiosis described himself and others who suffered the disease as the 'forgotten men' of the coalfields, the 'living dead of the mining industry', 'sentenced to a hopeless, destitute and empty future. ${ }^{104}$ Ferdynand Zweig similarly suggested some sense of this social isolation when he described sufferers of pneumoconiosis as 'a great number of men walking idly with grim, sullen faces and with a genuine grievance' through mining communities. ${ }^{105}$ The rhetorical aspects of these sources colour the 
portrayals here, but there is a strong sense in which impairment and disability were clearly and visibly marked.

\section{Public spaces: leisure and religion}

Apart from these interstitial spaces, mining communities were characterised by a range of particular public institutions, in addition to locations for the pursuit and consumption of leisure, that helped to create a sense of community. These institutions were just as crucial to the production and reproduction of social relations as the home and the workplace, and disabled miners found themselves enmeshed in a complex network of relations here too. Similar to the home and the workplace, these spaces were heavily gendered and were constructed according to clear and powerful ideas about the norms that should govern the daily lives of men and women.

In his study of the 'Little Moscows' of interwar Britain, Stuart Macintyre set out the most important social spaces of men in Maerdy in the Rhondda Fach valley and Lumphinnans in the Fife coalfield, and noted the pub, the cinema, the football match, the institute and the library as the main locations of male sociability and community formation. In contrast, the women of mining communities had fewer opportunities for social interaction, but shopping, the cinema and religion offered some scope for female sociability, even if such activities 'lacked the rich diversity, systematic character and purpose of intercourse among working men'. Macintyre also notes that the physical configuration and proximity of houses in the Maerdy terraces and the Lumphinnans rows encouraged female interaction, while the communal laundries and the 'greens' where washing was dried frequently brought women together in Lumphinnan's case. ${ }^{106}$ Similarly gendered spaces for men and women were observed in the north-east of England by Ernst Dückershoff. ${ }^{107}$

Such spaces changed over time and, in many cases, became more numerous as social facilities in mining communities were developed. Whether funded by employer paternalism, middle-class philanthropy or the miners' own efforts, the numbers of institutes, halls, cinemas and sporting spaces increased in the first half of the twentieth century and provided more opportunities for social interaction, though to a greater degree for men than women. ${ }^{108}$ This increase in community facilities was further encouraged by the formation of the Miners' Welfare Fund. The Mining Industry Act of 1920 introduced a tax of 1d. on each ton of coal raised in Britain for the accumulation of a fund to invest in miners' welfare through medical, educational and lesiure facilities; the building or maintenance of miners' institutes and sporting facilities was one of the most 
popular forms of provision made by the Fund, providing recreation and education to miners and their families. ${ }^{109}$

And yet the accessibility of these spaces to disabled people is uncertain. Those with mobility needs would have faced trouble getting into these new leisure spaces. As one disabled miner commented, 'a man's life is not confined to his work. He has a social life, and the consequence of an accident like the loss of a leg or an arm or an eye, was with him, when he was trying to enjoy some social life and domestic life, and not simply that he couldn't work. We're not simply cogs in a wheel. ${ }^{110}$ This was certainly the experience of Will Devereux, a pneumoconiotic miner from Glynneath in the Neath Valley. Such was his impairment that he was unable to walk the short distance from his home to the Miners' Welfare Hall, the 'centre of village life', unless he received some help to get there. 'So there is little he can do', it was commented, 'but sit at home, while his wife goes out to factory work.' ${ }^{\text {,11 }}$

In some instances, former work colleagues and other members of the community were important in breaking down the social isolation of former miners with impairments who might otherwise have had little opportunity to pursue their former leisure interests. Dick Cook, a blind miner, remembered the impact of his disability on his social life and the reaction of his friends:

If I wasn't seeing I was listening and that is the biggest thing I think of is loneliness when you are blind or deaf, things like that, loneliness. You can be lonely in a crowd unless you are spoken to, you can be in big crowds[.] I was many times and I remember your Dad used to take me to rugger matches ... [Y] our Dad [the interviewer's father] used to always put his arm under mine and tell me what was going on. ${ }^{112}$

Cook's interview shows the importance of relationshps within the community and with colleagues in gaining access to otherwise impossible spaces.

Physical access to these public spaces was an important means by which disabled miners came together, but it was also important as a means to access the support that the neighbourhood might extend to them in their poverty. Bert Coombes offers an instructive insight into the importance of the public house in this context of communal solidarity. After noticing a gravely ill friend sitting in the corner, Coombes learns that he has come to the pub to sell tickets to raffle his gramophone to raise money for his family in order to make ends meet. Coombes and his mate immediately buy more tickets than they can comfortably afford and another group of miners buy tickets without hesitation, while, interestingly, two railwaymen are initially relucant before eventually agreeing to do so. Coombes commented: 'you will never see a miner refuse help to another who is sick or injured, for it may be his own turn next; but the 
others who make up the mining communities may live with them for years and yet not take any interest in the problems of those who create the industry on which they live.. ${ }^{113}$

Apart from the means by which to access the communitarian spirit within mining communities, public houses also form a place of leisure. In the fiction of the coalfields, the pub and social club are shown as accessible, and regularly frequented by people with a range of disabilities (though not severe mobility impairments). Jack Jones's Black Parade (1935), a novel which depicts the fortunes of a Merthyr mining family from the 1880s to the early 1930s, portrays the various ways in which families could support disabled members, socially as well as materially. This is most frequently through the agency of the central character and mother, Saran, but male bonding around alcohol and the pub is also important. Ossie, a man blinded during the Great War, goes out drinking with his father- and brother-in-law, his 'hand on [Sam's] right shoulder'. He is carrying a half-crown given to him by another disabled man, his brother-in-law, Lewis, who has turned bookie after having a hip shattered in the war who is also planning 'to go out for the night and part of next morning. ${ }^{114}$ The pub is presented as an exclusively male space in this and other novels (when a young Saran enters a public house to find Glyn when the two are courting, he is mortified).

The male spaces of working-men's clubs offer another leisure space for men. 'What is a social club for but to sit about with your friends and talk?' asks the narrator of Rhys Davies's Jubilee Blues (1938). ${ }^{115}$ The aged and disabled are part of this social world - in person and as a topic of conversation. Significantly, the discussion of impairment is bound up with both industrial action and another typically male interest, sport. The 'older club members' sit talking 'of the old days' of 'strikes ... and limb-losses'. Among them is 'Ieuan Mold, ex-boxer, ex-collier, ex-married-man, ex-fighter in agitations of long ago, and saviour of two lives in a pit flood, whose battered face no one liked to look on for long in daylight, so misshapen it was. ${ }^{116}$ In one embodied figure is inscribed the cultural and 'misshapen' industrial history of the region. Ieuan's sporting days are behind him by the time he sits among the old men reminiscing, but disability did not automatically preclude men from engaging in the less formal forms of 'sport' which took place - at least not in the world of coalfields novels. The unregulated outdoor boxing matches depicted in Black Parade spill over into street fighting in which Harry, the former bare-fist boxing champion, continues to 'compete', despite having had a leg amputated after a mine accident: 'fighting with his back 'gainst the wall and his peg drove into the ground.' ${ }^{117}$

While sport and leisure were important areas of male sociability that might or might not be accessed, depending on the severity of impairment and the quality of relations with others in the community, perhaps the most important 
community space for many inhabitants of mining communities was the church or chapel. The three regions were distinctive in their religious traditions. Broadly, the dominant institutions were the Presbyterian Church in Scotland, Primitive Methodism in the colliery districts of the north-east of England and Calvinistic Methodism and a handful of other nonconformist denominations, including the Congregationalists, in south Wales, where the chapels were often at the heart of Welsh-speaking communities. In all three regions Catholicism was regarded with some suspicion as connected with the poverty and purportedly lax morality of Irish immigrants. ${ }^{118}$

In the north-east of England, Robert Colls has argued: 'the heroic relationship of Methodism and Mining in the industrial revolution, a legend even today [1977], was a cliché by $1907 .{ }^{\prime 19}$ Coalfields novels, many of them written by ministers and published by religious presses, contributed to this picture. A prominent feature of many of the late nineteenth- to early twentieth-century novels is the role of mining accidents in religious conversion. The routine accidents of the pit, rather than the major disasters, are a way of calling a man's attention to his bodily frailty. The spiritual salvation which results makes injury and even permanent disability welcome. The Black Diamond (1880), by Hugh Gilmore, portrays the conversion of the wild Ralph Lowton following a serious crush injury which renders him a temporary 'invalid' and puts him on the path to spiritual and social betterment. ${ }^{120}$ One pious collier remarks: 'Who knoweth but this young man may have to say like the psalmist, "It was a good thing for me that I was afflicted?" ${ }^{121}$ Amen. May the Lord use his bodily affliction to the recovery of his soul. ${ }^{122}$ It is a sentiment repeated in Harry Lindsay's Rhoda Roberts (1895) when a miner claims, 'what we sometimes call accidents are merciful dispensations of an All-wise Providence. ${ }^{123}$ This view is immediately contested, as another miner takes issue with the idea that mass death and injury is the will of God. Thus, while physical injury may be connected to individual salvation, large-scale disaster should not be seen as divine punishment of a community. ${ }^{124}$ In general, injury or disability leading to religious conversion focuses on the individual, an emphasis which is rooted in Methodist interest in personal revelation: 'some sort of personal experience of salvation was, at the beginning of the period [1870-1926], almost an essential requirement for becoming a Methodist.' ${ }^{125}$

Although religion was on the wane in the twentieth century, it remained a significant community presence. Despite the prominence of religion in coalfields literature, however, there are few historical records which shed light on the particular relationship of chapels and churches to disabled people or the experience of disabled members of different congregations in the Sunday service or in other social activities arranged by and within places of worship. The very 
architecture of places of worship could of course exclude people with impaired mobility, as Nancy Eiesland points out in The Disabled God, noting her own experience of being denied eucharist as a consequence. ${ }^{126}$ Nevertheless, some church community support groups, such as the St James United Reformed Church Newcastle Women's Guild, founded in 1930 to provide services, including taking patients to and from hospitals and visiting people in their homes, certainly demonstrated a concern for the well-being of disabled people and offered different forms of support. ${ }^{127}$ Ernst Dückershoff was impressed by the activities of chapels and churches in mining communities in the north-east of England on behalf of families in need. ${ }^{128}$ Such welfare activities on behalf of injured and sick miners and their families indicate perhaps some measure of concern and engagement that might have lessened any feelings of social isolation, but arguably also made disabled people the objects of charity, with all that that implied. ${ }^{129}$

By the interwar period, with a predominance of literary texts written by working-class authors with strong political convictions, disability becomes part of the emerging struggle between socialism and nonconformity. The chapel tends to be seen no longer as a radical friend of the labouring poor and working classes, but as a place that excludes the poor (who are dirty and ragged and therefore not godly) and, in some cases, disabled people. ${ }^{130}$ Ellis Lloyd's Scarlet Nest (1919) includes a disabled collier boy, Dafydd, who has been severely burned, paralysed and brain damaged in a colliery explosion. The socialist Owen John, a fellow collier, helps Dafydd by paying for him to go on all the 'treats' put on by chapels. But this is strongly resisted by the inflexible deacon Hezekiah. Thus Owen John, the supposed atheist, embodies Christian love and fellowship by supporting Dafydd out of a sense of solidarity, while the chapels are exposed as self-serving 'strongholds of the modern Pharisees and the Capitalists.' ${ }^{131}$

Following the 1926 General Strike, tensions only increased as the oppositional stance of the established Presbyterian church in Scotland and some nonconformist denominations meant many miners 'ever after regarded the mainstream Christian churches as agents of capital. ${ }^{132}$ This divide between chapel and worker is a recurring theme, often involving disability. In 'The Benefit Concert' (1946), as mentioned in Chapter 2, Rhys Davies subverts the tradition of chapel-led charity. The concert of the title is to provide funds for a prosthetic leg for a miner, Jenkin. The money raised is significantly in excess of that required for the leg (given as $£ 100$, of which $£ 1$ was spent on the leg), and Jenkin wants to use the extra to set up a tobacco shop, thus securing an independent livelihood. Rather than support the disabled man, the chapel deacons (described as 'business men') announce 'on the glory of Horeb the extra money will be spent. ${ }^{133}$ The material prosperity of the chapels, set against the abject poverty of the colliery districts during the Depression, was also the focus of scathing attack by the 
satirist Gwyn Thomas, who regularly used disability and black humour to ram home his point. His novel Sorrow for Thy Sons (c.1936) includes diatribes against the grasping materialism of the chapel which directly leads to disablement. ${ }^{134}$ One member, Charlie, has been starving his children in favour of paying handsomely for chapel membership, to the despair of political activist Howells:

Rickets, Charlie, it's rickets. It hasn't got anything to do with heaven or hell, sin or goodness, except that those people who allow kids to develop rickets are committing a sin for which the punishment should be some form of hell on earth. Rickets come from lack of food. Your kids lack food more than they ought to, because you go handing three or four bob a week over to the Apostolic pastor, so that he can eat enough on earth to avoid rickets in the life after, or that somebody can decorate the walls of that tin shanty you call your church with some new season blooms. ${ }^{135}$

This tirade calls out the hypocrisy of expecting the wages of the working classes to fund bourgeois frivolities such as 'new season blooms', and to enable a relatively luxurious lifestyle for the middle-class pastor, humorously suggesting that he can overeat to the extent that he is well nourished in the afterlife. As well as attacking the sanctimonious ideology that welcomes suffering as mortification of the spirit - roundly condemned in much coalfields literature - the novel draws the reader's attention to the wider casualties of industrial society in this period of mass unemployment. The people marked, or disqualified, by 'diseases' of poverty are excluded from the dogmatic and hypocritical values of certain strains of chapel religion that ascribe moral value to a clean, healthy, middle-class appearance. As a consequence, 'God's image will become more and more the exclusive property of the middle and upper classes ... the unemployed masses [will] see that godliness is only another form of that jobliness which is denied them. ${ }^{136}$ In writers such as Thomas we can see challenges to the stigmatising, exclusionary and disempowering narratives and structures found in some aspects of religious culture, discussed further in Chapter 6. Thomas is drawing on an alternative moral view based on socialism, challenging the Christian alignment of bodily perfection and moral purity for disenfranchising the working classes, whose bodies were made imperfect by working conditions, unemployment or deprivation. While the limited historical sources suggest that organised religion did try to provide some charity directly targeted at disabled members, many working-class coalfields writers cast doubt on the social role of chapels within a capitalist system and on the workings of charity itself.

While sources exist to suggest the ways in which impaired men accessed and experienced social and community spaces, it is far more difficult to ascertain the experiences of disabled women. Few sources suggest how women experienced these spaces, but, at the same time, women had little access to public houses, 
sporting venues or other spaces in the community. Bill Williamson, writing about the Northumberland pit community of Throckley in the early twentieth century emphasises the narrowness of women's lives and the extent to which they were focused on the domestic tasks of the home. Such was the timeconsuming and arduous nature of those tasks that a woman had little time for leisure outside or far beyond the confines of the home and, instead, faced a 'kind of imprisonment, a grinding necessity' in which 'her work and her leisure were fused.' ${ }^{137}$ This left the immediate neighbourhood as the place in which women's social lives were lived and experienced in mining communities, and Williamson emphasises the importance of the social networks that were built and maintained in these spaces:

Maintaining the links of neighbourliness and friendship was a central theme in her working life, part of the business being a pitman's wife. Thinking about these things, being concerned about them was another essential part of being a housewife; without those contacts her life would have been considerably impoverished and insecure. ${ }^{138}$

Valerie Gordon Hall notes the increase in lesiure opportunities for young women in mining communities in the interwar period, and the importance of the church and chapel for women's social lives, but sources offering any perspective on the experience of disability in such contexts are lacking. ${ }^{139}$ This is, in itself, indicative of the invisibility of female impairment in mining communities.

\section{Conclusion}

It is no easy task to study the social relations of disabled miners. They were made and remade in the numerous mundane, quotidian encounters in face-to-face situations that nobody would have thought to record at the time. Only through autobiographical accounts such as oral history interviews or through portrayals of mining communities, whether by insiders such as Bert Coombes or outsiders such as Ernst Dückershoff or Ferdynand Zweig, can we piece together something of these relations. More importantly, such social relations were extremely complex, dependent on so many different factors and intersections, and dependent on personal dynamics, so that relations between different individuals were all unique in their own particular ways. Significantly, however, a greater challenge is posed by the fact that it was interactions in the past that generated comment or some trace in the sources, whereas the absence of such contact has failed to leave any mark: social isolation leaves only silences in the sources.

Nevertheless, even in the face of imperfect source material, it is possible to glimpse the social relations into which disabled people in coalfield communities 
entered. As individuals, they sat at the heart of a complex web of social relations that reached from the home into the neighbourhood, and beyond into the wider community. Disabled people in mining regions faced undoubted social isolation, but it was not as complete in this particular context as some works on disability studies have insisted, nor did they necessarily suffer the totality of 'socio-spatial exclusion' that Gleeson discerns in other contexts. ${ }^{140}$ Gleeson might have discerned the 'disabling city' in nineteenth-century Manchester and Melbourne, but, with this more empirical approach to mining communities, it is more difficult to discern 'disabling coalfields' to quite the same degree, and the complexities and varieties of disabled people's experiences need to be recognised. ${ }^{141}$

\section{Notes}

1 On the 'spatial turn', see Fiona Williamson, 'The Spatial Turn of Social and Cultural History: A Review of the Current Field', European History Quarterly, 44:4 (2014), pp. 703-17; Ralph Kingston, 'Mind Over Matter? History and the Spatial Turn', Cultural and Social History, 7:1 (2010), pp. 111-21; Leif Jerram, 'Space: A Useless Category for Historical Analysis?', History and Theory, 52:3 (2013), pp. 400-19.

2 Brendan Gleeson, 'Domestic Space and Disability in Nineteenth-Century Melbourne, Australia', Journal of Historical Geography, 27:2 (2001), pp. 223-40; see also his 'Recovering a "Subjugated History": Disability and the Institution in the Industrial City', Australian Geographical Studies, 37:2 (1999), pp. 114-29.

3 B. J. Gleeson, Geographies of Disability (London: Routledge, 2002), p. 27.

4 Jerram, 'Space: A Useless Category', p. 402.

5 For some examples of work that considers the home as integral to the creation of social relations in mining communities, see Valerie G. Hall, Women at Work, 1860-1939: How Different Industries Shaped Women's Experiences (Woodbridge: Boydell Press, 2013); Alan Campbell, The Scottish Miners, 1874-1939. Volume One: Industry, Work and Community (Aldershot: Ashgate, 1999).

6 Jenny Morris, Pride against Prejudice: Transforming Attitudes to Disability: A Personal Politics of Disability, reprint edition (London: The Women's Press Ltd, 1991), p. 10.

7 For two examples, see Kim Q. Hall (ed.), Feminist Disability Studies (Bloomington: Indiana University Press, 2011); Alison Piepmeier, Amber Cantrell and Ashley Maggio, 'Disability Is a Feminist Issue: Bringing Together Women's and Gender Studies and Disability Studies', Disability Studies Quarterly, 34:2 (2014), http:// dsq-sds.org/article/view/4252, accessed 5 August 2016.

8 Tom Shakespeare, 'The Sexual Politics of Disabled Masculinity', Sexuality and Disability, 17:1 (1999), p. 55.

9 For an early example, see John Benson, British Coalminers in the Nineteenth Century: A Social History (Dublin: Gill and Macmillan, 1980). Also important is M. J. 
Daunton, 'Miners' Houses: South Wales and the Great Northern Coalfield, 1880-1914', International Review of Social History, 25:2 (1980), pp. 143-75.

10 Griselda Carr, Pit Women: Coal Communities in Northern England in the Early Twentieth Century (London: Merlin, 2001), p. 69.

11 Campbell, The Scottish Miners, 1874-1939. Volume One, pp. 217-18.

12 Benson, British Coalminers in the Nineteenth Century, pp. 95-8.

13 Campbell, The Scottish Miners, 1874-1939. Volume One, pp. 219-20.

14 Daunton, 'Miners' Houses', p. 171.

15 Campbell, The Scottish Miners, 1874-1939. Volume One, p. 216.

16 Carr, Pit Women, pp. 65-6. Bert Coombes noted the sufferers of pneumoconiosis who were required to spend their nights sitting up in a chair to sleep because they would not be able to catch their breath lying down; B. L. Coombes, Those Clouded Hills (London: Cobbett Publishing Co. Ltd., 1944), p. 56.

17 Mass Observation Archive, SxMOA1/2/64/1/B/1, Typescript of report on Blaina and Nantyglo, October 1942.

18 Carol White and Sian Rhiannon Williams (eds), Struggle or Starve: Women's Lives in the South Wales Valleys between the Two World Wars (Dinas Powys: Honno, 1998), p. 10.

19 Carr, Pit Women, p. 68.

20 Carr, Pit Women, p. 71.

21 South Wales Miners' Library, Swansea University (hereafter SWML), AUD/164, John Morgan Evans oral history interview.

22 Gwent Archives, CSWBGB/C/32, Bedwellty Union Out Relief Advisory Committee Papers, 29 December 1926; see also, White and Williams, Struggle or Starve, pp. 161-74.

23 For examples, see Mitchell Library, Glasgow City Archives (hereafter ML), CO1 27 95, Applications for Poor Relief, Carluke, 1898-1902.

24 West Glamorgan Archives Service (hereafter WGAS), D/D SHF, Swansea Hospital Ladies' Samaritan Fund Minutes, 12 February 1926; 9 November 1928.

25 For a literary study on the topic of care work, disability and mining wives see Alexandra Jones, "'Her Body [was] Like a Hard-Worked Machine”: Women's Work and Disability in Coalfields Literature, 1880-1950', Disability Studies Quarterly, 37:4 (2017).

26 The Miner, August 1946, pp. 6-7.

27 Enid M. Williams, The Health of Old and Retired Miners in South Wales (Cardiff: University of Wales Press Board, 1933), p. 22. See also the discussion of miners' health and care in relation to marches in Chapter 6.

28 Ramsay Guthrie, Black Dyke (London: Charles H. Kelly, 1904), p. 29.

29 Guthrie, Black Dyke, pp. 5-6.

30 Similarly, the paralysed miner in J. C. Grant's novel The Back-to-Backs (London: Chatto and Windus, 1930) receives care from both his sister and a male family friend. 
31 See also Gwyn Jones's Times Like These (London: Victor Gollancz, 1979 [1936]), where Olive receives care from her unemployed collier husband.

32 Jack Jones, Bidden to the Feast (London: Corgi Books, 1968 [1938]), pp. 76-7.

33 Jack Jones, Unfinished Journey (London: Hamish Hamilton, 1938), p. 96.

34 Harold Heslop, The Earth Beneath (London: T. V. Boardman and Company Ltd., 1946), p. 83.

35 Heslop, The Earth Beneath, p. 290.

36 Heslop, The Earth Beneath, p. 290.

37 Heslop, The Earth Beneath, p. 291.

38 Heslop, The Earth Beneath, pp. 290-1.

39 Harold Heslop's father was a Methodist preacher; Methodism is treated in this novel as part of the history of political activism among the miners and a vital aspect of the formation of the first trade unions. Butch, for example, is an agitator for the Union as well as a lay preacher. On the topic of Methodism and politics in the Durham mining community, see Robert Moore, Pit-men, Preachers and Politics: The Effects of Methodism in a Durham Mining Community (Cambridge: Cambridge University Press, 1974.)

40 Heslop, The Earth Beneath, p. 292.

41 Joe Corrie, Black Earth (London: Routledge, 1939), p. 227.

42 E. L. Collis and Major Greenwood, The Health of the Industrial Worker (London: Churchill, 1921), p. 409.

43 SWML, AUD/238, Dai Daniel Rees interview.

44 Scottish Oral History Centre (hereafter SOHC), John Paterson interview, 1998. It is with such experiences in mind that some miners could characterise sons as 'capital for your old age'; too many daughters, on the other hand, was considered by some as 'the dark tragedy of the mining family'; Jim Bullock, Bowers Row: Recollections of a Mining Village (Wakefield: E. P. Publishing, 1976), pp. 65, 77.

45 Marjorie Levine Clark, 'The Gendered Economy of Family Liability: Intergenerational Relationships and Poor Law Relief in England's Black Country, 1871-1911', Journal of British Studies, 45:1 (2006), pp. 72-89; Clark discerns a more widespread use of the 'liable relatives clause' from the 1870 s onwards as part of the 'crusade' against out-relief (p. 78).

46 The Aberdare Times, 13 October 1894.

47 For example, see Thirty-Fifth Annual Report of the Board of Supervision for the Relief of the Poor and of Public Health of Scotland, 1879-80, c. 2661, 1880, xxviii, 'Report by General Superintendant of the Poor, Southern (Highland) District, for the Half-Year ended 31st March 1880', p. 8.

48 Gwent Archives, Bedwellty Union Out Relief Advisory Committee papers, 18/20 October 1926.

49 Stuart Macintyre, Little Moscows: Communism and Working-Class Militancy in Inter-War Britain (London: Croom Helm, 1980), p. 137.

50 Campbell, The Scottish Miners, 1874-1939. Volume One, p. 236. 
51 Gwent Archives, CSWBGB/C/30, Bedwellty Union Relief Advisory Committee Papers, 1925 and 1926.

52 For examples, see Carr, Pit Women, p. 52; SWML, AUD/164, John Morgan Evans oral history interview.

53 SOHC, Iain McDougall Coal Mining Oral History Project, interview with Janet Chapman, 1999.

54 This potentially complicates the contested place of arts and crafts in the history of disability as individually chosen rehabilitation and social readjustment rather than inherently patronising. See, for example, Carolyn Malone, 'A Job Fit for Heroes? Disabled Veterans, the Arts and Crafts Movement and Social Reconstruction in Post-World War I Britain', First World War Studies, 4:2 (2013), pp. 201-17.

55 Mike Mantin, “"From Pithead to Sickbed” Exhibition Blogs: George Preece, Disabled Miner', Disability and Industrial Society website, http://www.dis-ind-soc.org.uk/ en/blog.htm?id=45, accessed 30 August 2018.

56 South Wales Miners' Federation, To the Bedwas Workmen and Their Womenfolk (Caerphilly: Owen Jones, 1936).

57 The Cambrian, 29 July 1887 , p. 3.

58 Bullock, Bowers Row, pp. 18, 23.

59 SOHC, Iain McDougall Coal Mining Oral History Project, interview with Janet Chapman, 1999.

60 Several disability theorists discuss disability as a 'master trope of disqualification'; see, for instance, Toibin Siebers, Disability Aesthetics (Ann Arbor: University of Michigan Press, 2010), p. 27.

61 For further examples, see J. C. Grant's North-East English novel The Back-to-Backs (1930) and Scottish miner Tom Hanlin's romantic novel Yesterday Will Return (New York: The Viking Press, 1946). In The Back-to-Backs the paralysed miner, Tom, is frustrated by falling in love with his brother's wife, and focuses on feelings of sexual impotence. The plot of Yesterday Will Return is driven by the suspicious death of a paralysed miner, Matt, who broke his back a week after they were married and died falling from his bed; his wife, Mima, a femme fatale type of character, is suspected of murdering him for the lump-sum compensation.

62 Corrie, Black Earth, p. 224.

63 Corrie, Black Earth, p. 246.

64 Shakespeare, 'The Sexual Politics of Disabled Masculinity', p. 58.

65 Corrie, Black Earth, p. 182.

66 Corrie, Black Earth, p. 255.

67 Carr, Pit Women, p. 72.

68 On working-class women's health and disability, see M. Ll. Davies, Life as We Have Known It (London: J. and A. Churchill, 1931); M. Spring Rice, WorkingClass Wives: Their Health and Conditions (Harmondsworth: Penguin Books, 1939).

69 Durham County Record Office, U/EA 12, Easington Union Board of Guardians' Minutes, 27 June 1912. 
70 Joanna Bourke, Working Class Cultures in Britain, 1890-1960: Gender, Class, and Ethnicity (London: Routledge, 1994).

71 Sue Bruley, The Women and Men of 1926: A Gender and Social History of the General Strike and Miners' Lockout in South Wales (Cardiff: University of Wales Press, 2010), p. 21; see also Carr, Pit Women, p. 33.

72 Carr, Pit Women, p. 68.

73 For an obituary of Eos Wyn, see Cwrs y Byd, May, 1892, pp. 81-4. The title of his column suggests he was aware of, and influenced by, the writings of Harriet Martineau; see [Harriet Martineau], Life in the Sick-Room. Essays by an Invalid (London, 1844). See, also, Maria H. Frawley, Invalidism and Identity in NineteenthCentury Britain (London: University of Chicago Press, 2004).

74 Y Gwladgarwr, 24 December 1870, p. 2; 31 December 1870, p. 3; 11 February 1871, pp. 2-3; 18 February 1871, p. 3; 4 March 1871, p. 2; 11 March 1871, p. 2.

75 Y Gwladgarwr, 13 January 1872, p. 2.

76 Y Gwladgarwr, 24 August 1872, p. 2.

77 Y Gwladgarwr, 1 June 1872, p. 5.

$78 Y$ Gwladgarwr, 5 September 1874, p. 6.

79 See, for example, Jones, Times Like These and Richard Llewellyn, How Green Was My Valley (London: Penguin Books, 1991 [1939]).

80 Jack Jones, Rhondda Roundabout (London: Hamish Hamilton, 1949 [1934]), p. 98.

81 James Hanley, Grey Children: A Study in Humbug and Misery in South Wales (London: Methuen, 1937), p. 255.

82 SOHC, Iain McDougall Coal Mining Oral History Project, Willie McGill interview, 4 September 1999.

83 Gleeson, 'Domestic Space and Disability in Nineteenth-century Melbourne'. Similar to what we find in relation to coalfield communities, Gleeson noted that disabled people were a common sight on the streets of nineteenth-century Melbourne and that their bodily differences were often very evident.

84 Gleeson, Geographies of Disability, p. 99.

85 Jules Ginswick (ed.), Labour and the Poor in England and Wales 1849-1851: The Letters to The Morning Chronicle. Vol. III The Mining and Manufacturing Districts of South Wales and North Wales (London: F. Cass, 1983), p. 49.

86 'Socialist Campaign in South Wales', Commonweal, 27 August 1887, quoted in Ken John, 'Sam Mainwaring and the Autonomist Tradition', Llafur, 4:3 (1986), p. 65.

87 Ferdynand Zweig, Men in the Pits (London: Society of Friends, 1948), p. 5.

88 Ernst Dückershoff, How the English Workman Lives (London: P. S. King \& Son, 1899), p. 93.

89 Gerald Porter, 'The English Ballad Singer and Hidden History', Studia Musicologica, 49:1/2 (2008), p. 141; Roy Palmer, The Sound of History: Songs and Social Comment (Oxford: Pimlico, 1988), pp. 92-7. 
90 The Tommy Armstrong Society website, http://www.pitmanpoet.org.uk/Welcome/ welcome.htm, accessed 14 August 2018. See also Palmer, The Sound of History, pp. 28-9, 96-7.

91 Elizabeth Bredburg, 'Writing Disability History: Problems, Perspectives and Sources', Disability and Society, 14:2 (1999), pp. 194-5.

92 David White, Mwnwr tlawd, yr hwn a gafodd niwaid mawr dan y ddaear (Caerfyrddin, n.d.); Anon., Cwyn y cloff (n.d.). Digital copies of both texts are held at Welsh Ballads Online: https://www.library.wales/discover/library-resources/ballads/. Mwnwr tlawd: http://hdl.handle.net/10107/1106801 and Cwyn y cloff: http:// hdl.handle.net/10107/1101239 (accessed 24 September 2019).

93 Y Goleuad, 13 Hydref 1905, p. 10. Turning to literature to make a living was common across the coalfields. For instance, William Francis Barnard (1840-1903), a miner born at Red Row, Clackmannanshire, started selling poetry when his son, Andrew, was injured in the mine and he needed extra money because of lost income; D. Edwards, Modern Scottish Poets v.10 (Brechin: D. H. Edwards, 1887), p. 292. Andrew Barnard (1860-?), slowly recovered from this accident, mastering a variety of crafts (knitting and lace-making, along with joinery, fretwork and tailoring), and became a poet himself. Perhaps inspired by the success of the two Barnards, a collier friend of Andrew's, James Ballantyne (1860-87), also turned to poetry following a mining accident which left him partially paralysed. James and Andrew 'often rhymed and talked together', suggesting that they influenced each other's work; D. Edwards, Modern Scottish Poets v.13 (Brechin: D. H. Edwards, 1890), pp. 132-3.

94 Y Cantwr Dall, neu amgylchiadau William Bowen, Y Cantwr (Aberdare: Jones \& Son, c.1873-87).

95 Rosemarie Garland Thomson, Extraordinary Bodies: Figuring Physical Disability in American Culture and Literature (New York: Columbia University Press, 1997), p. 13.

96 Thomson, Extraordinary Bodies, p. 13.

97 Campbell, The Scottish Miners, 1874-1939. Volume One, pp. 222-3.

98 Grant, The Back-to-Backs, p. 202.

99 B. L. Coombes, Miners Day (Harmondsworth: Penguin, 1945), p. 113.

100 Enid M. Williams, The Account of an Investigation into the Health of Old and Retired Coalminers in South Wales (Cardiff: University of Wales Press, 1933), p. 1; see also p. 40 .

101 Coombes, Those Clouded Hills, p. 56.

102 Amman Valley Chronicle, 3 March 1938, p. 8.

103 Gleeson, 'Domestic Space and Disability in Nineteenth-Century Melbourne', p. 227.

104 The Miner, December 1944, p. 14.

105 Zweig, Men in the Pits, p. 103.

106 Macintyre, Little Moscows, p. 139.

107 Dückershoff, How the English Workman Lives, pp. 39, 55-75. 
108 Robert James, Popular Culture and Working-Class Taste in Britain, 1930-39: A Round of Cheap Diversions? (Manchester: Manchester University Press, 2014); Peter Bailey, Leisure and Class in Victorian England: Rational Recreation and the Contest for Control, 1830-1885 (London: Methuen, 1987); Daryl Leeworthy, Fields of Play: Sporting Heritage of Wales (Aberystwyth: Royal Commission on the Ancient \& Historical Monuments of Wales, 2012).

109 Viscount Chelmsford, The Miners' Welfare Fund (London: HMSO, 1927); W. John Morgan, 'The Miners' Welfare Fund in Britain 1920-1952', Social Policy of Administration, 24:3 (1990), pp. 199-211

110 SWML, AUD/382, D. C. Davies oral history interview.

111 Picture Post, 27 January 1945, p. 18.

112 SWML, AUD/222, Dick Cook interview.

113 B. L. Coombes, These Poor Hands: The Autobiography of a Miner Working in South Wales, with an Introduction by Bill Jones and Chris Williams (Cardiff: University of Wales Press, 2002), p. 165.

114 Jack Jones, Black Parade (Cardigan: Parthian, 2009 [1935]), pp. 413, 342.

115 Rhys Davies, Jubilee Blues (London: Heinemann, 1938), p. 222.

116 Davies, Jubilee Blues, p. 222.

117 Jones, Black Parade, p. 412.

118 Key works of literature were produced by Catholic miners, including the ex-miner writers Joseph Keating in Wales and Tom Hanlin in Scotland.

119 Robert Colls, The Collier's Rant: Song and Culture in the Industrial Village (London: Croom Helm, 1977), p. 164.

120 Hugh Gilmore, The Black Diamond: A Tale of Life in a Colliery Village (London: Thomas Mitchell, Primitive Methodist Publishing House, 1880), p. 60. Gilmore (1842-91) was born in Glasgow. A homeless orphan, he trained briefly as a bottle-maker's apprentice in Liverpool before moving to Newcastle-upon-Tyne, where he converted to the Primitive Methodist church. He became a lay preacher, and later an itinerant preacher, travelling the northern circuits, including Weardale and Darlington. He was a well-known and popular speaker, as well as writing numerous articles under his initials 'H. G.' for Methodist magazines such as the Christian Ambassador.

121 The reference is to Psalm 119:71.

122 Gilmore, The Black Diamond, p. 49.

123 Harry Lindsay, Rhoda Roberts: A Welsh Mining Story (London: Chatto and Windus, 1895), p. 8. Henry Lindsay Hudson (1858-1926) was born in Belfast, educated in Liverpool, and worked as a teacher for a period in Wales. A lay preacher and Steward of the Weslyan Methodists, he also worked as a journalist.

124 For a helpful short overview of the ways in which disability is interpreted in various ways as a function and sign of [the] proximity' to 'the human life-world' of 'the divine and metaphysical orders' (p. 6) - from antiquity to the present - see Ato Quayson, Aesthetic Nervousness: Disability and the Crisis of Representation (New York: Columbia University Press, 2007), pp. 5-9. 
125 Robert Moore, Pit-men, Preachers and Politics: The Effects of Methodism in a Durham Mining Community (Cambridge: Cambridge University Press, 1974), p. 23.

126 Nancy Eiesland, The Disabled God: Toward a Liberatory Theology of Disability (Nashville: Abingdon Press, 1994), p. 100.

127 Tyne and Wear Archives Service, C.NC7/1/18/1, St James' United Reformed Church, Northumberland Road, Newcastle, Women's Guild Minutes, 1930-3.

128 Dückershoff, How the English Workman Lives, pp. 84-7.

129 In this context, see A. J. Kidd, 'Philanthropy and the "Social History Paradigm"', Social History, 21:2 (1996), pp. 180-92.

130 Richard Llewellyn's How Green Was My Valley (1939) is a significant exception and the relationship between religion and literature is discussed in Chapter 6.

131 Ellis Lloyd, Scarlet Nest (London: Hodder and Stoughton, 1919), p. 189.

132 Callum G. Brown, Religion and Society in Twentieth-Century Britain (Harlow and New York: Pearson Longman, 2006), p. 157.

133 Rhys Davies, 'The Benefit Concert', in Rhys Davies and Meic Stephens (ed. and intro.), Collected Stories: Volume II (Llandysul: Gomer Press, 1996), pp. 17-25.

134 Sorrow for Thy Sons was published posthumously in 1986, but was written during the 1930s.

135 Gwyn Thomas, Sorrow for Thy Sons (London: Lawrence and Wishart, 1986), p. 234.

136 Thomas, Sorrow for Thy Sons, pp. 238-9.

137 Bill Williamson, Class, Culture and Community: A Biograhical Study of Social Change in Mining (London: Routledge \& Kegan Paul, 1982), pp. 132, 131.

138 Williamson, Class, Culture and Community, pp. 130-1.

139 Gordon Hall, Woman at Work, pp. 61-4.

140 On the social isolation of disabled people in industrialisation, see Michael Oliver, The Politics of Disablement (London: Macmillan, 1990); Gleeson, 'Domestic Space and Disability in Nineteenth-Century Melbourne', esp. pp. 225-6.

141 Gleeson, Geographies of Disability, p. 106. 